\title{
ALERT-India 1981-89: nine years' experience of leprosy control in the slums of Bombay
}

\author{
A A SAMY, J MANCHERIL, K P MANEK \& \\ A C McDOUGALL* \\ Alert-India; Association for Leprosy Education, Rehabilitation and \\ Treatment-India, 6-B Mukhyadhyapak Bhavan, 3rd Floor, Sion \\ (West), Bombay 400 022, India; and *Department of Dermatology, \\ The Slade Hospital, Headington, Oxford, OX3 7JH, England
}

Accepted for publication 19 April 1991

\begin{abstract}
Summary Bombay has a population of about 8 million people, one-half of whom live in slums. In 1981, ALERT-India started its first leprosy control project in N, S and T Wards of Greater Bombay Municipal Corporation covering an area of $122 \mathrm{sq} \mathrm{km}$ in the north-eastern suburbs of Vidhyavihar, Ghatkopar, Vikhroli, Kanjurmarg, Bhandup and Mulund, with a total population of $1,100,000$ according to the 1981 census. In the 9 years of operation, over 12,000 patients have been registered and treated and of these 7425 have been released from treatment, having satisfactorily completed courses of chemotherapy. However, over 1000 cases are still identified every year by house-to-house or school surveys, or by self-reporting, including a considerable percentage in children. The origin, development, staff structure, operational procedure, administration and recording system of ALERT-India are described in detail, with emphasis on what has been accompolished with purely outpatient facilities, using paramedical workers, all of whom have received inservice training from Government recognized training centres for their specific tasks. The account includes a brief description of an expansion of the organization's work into townships in New Bombay, where preliminary surveys in 1988 confirmed the presence of leprosy cases and the need for treatment facilities. The discussion addresses: 1, the better use of the large volume of statistical information which has been collected by ALERT-India during the past 9 years, with emphasis on its value in assessing the impact on the control programme and modifying future policy; 2 , the need to radically examine the present policy of survey, versus an 'education campaign approach' with regard to increasing early case-detection and self-reporting; 3 , the establishment of a central coordinating body for leprosy control in Bombay to exchange information, coordinate efforts and formulate a future plan of action, the latter in association with the National Leprosy Eradication Programme; and 4, the development of a health education resource centre in association with the Bombay Municipal Corporation.
\end{abstract}




\section{Introduction}

ALERT-India was founded in October 1978. The letters stand for 'Association for Leprosy Education, Rehabilitation and Treatment' and this organization in India should not be confused with the All-Africa Leprosy and Rehabilitation Training Centre, also called ALERT, in Addis Ababa, Ethiopia. ALERT-India is registered under Acts of 1860 and 1950; it is a registered charity with audited accounts and donations are exempt from tax. The main financial support up to 1984 was from OXFAM (UK); from 1985 onwards it came from the Damien Foundation (Belgium) and other ILEP agencies such as the Associazione Italiana Amici de Raoul Follereau (Italy), Institute Fame Pereo (Canada) and the Association Francaise Raoul Follereau (France). The Damien Foundation is the ILEP Coordinator in India for finance and technical supervision. Its main objective is the eradication of leprosy, but the full list of subsidiary objectives as formulated and adopted by the Founder Members in October 1978 is as follows:

1 To detect early and infectious cases of leprosy in the community and reach the goal of total case detection through intensive surveys.

2 To treat every person diagnosed as suffering from active leprosy with adequate caseholding.

3 To create leprosy consciousness among the sections of the community through intensive health education programmes.

4 To work ardently towards total prevention of dehabilitation and promote sociopsychological and economic rehabilitation of leprosy patients in the milieu of the community.

5 To undertake and promote study and research in leprosy and related sciences.

To reach these objectives, three phases were envisaged.

\section{Phase One}

1 The establishment of a control programme and personnel to implement it; and

2 Bringing the maximum area under the Urban Leprosy Control Programme of the Association.

These would entail undertaking the following activities:

(a) conducting on-going surveys (house-to-house) in the project areas;

(b) progressively establishing treatment centres in surveyed areas;

(c) carry out a widespread programme of education particularly towards removal of existing deep-rooted prejudice and bias against the disease and its victims;

(d) setting up the office and records system (data collection, tabulation, analysis and control);

(e) establishment of a laboratory and a physiotherapy centre;

(f) publicising ALERT's aims, objectives and involvement, gaining community goodwill and cooperation at large, and the mobilization of local resources.

\section{Phase Two}

1 Establishment of a mini-hospital for special cases together with a full-fledged physiotherapy (physical rehabilitation centre); and 
2 Health education Centre;

3 Undertake and promote study and research.

\section{Phase Three}

1 Implementing the economic, occupational, rehabilitation programmes;

2 Promotion of an Urban Training Centre (woefully lacking) and the establishment of a social research wing to promote the cause of eradication. Depending upon the progress made, funds available and the situation then prevailing, it will quite likely be possible to dovetail the phases into each other and thereby implement the programme more expeditiously and effectively.

\section{Board of management}

ALERT-India has a Board of Management of 9 members, most of whom have been on the Board since at least 1983; some were in fact founders of the Association. Some are medically qualified and experienced in leprosy, others have backgrounds in community or social work, education, nursing or administration. The Board is the legal body responsible for the Association and the overall policy decisions/directives and sanctions. The Chief Executive is an Ex-officio member of the Board of Management. Project planning, implementation and day-to-day administration are delegated to the Chief Executive, who carries out tasks through his team of officers and field staff. He also acts as Project Holder for the sponsoring agencies on behalf of the Association and as the 'Reporting Trustee' to the Governments and their departments.

\section{Buildings, offices, clinics}

The main administrative office is convenient to the centre of Bombay and is used by the Chief Executive and office staff. For field work and administration, two large rooms were acquired in 1985 in an industrial block in the heart of the control area, Vikhroli. This 'Project Office' includes a laboratory for slit-skin smears, storeroom, office accommodation, a teaching or meeting area and space for the reception and treatment of patients at a weekly clinic.

\section{The project area}

The area allocated is that of the three wards N, S and T as shown in Figure 1. These wards include the areas known as Vidyavihar, Ghatkopar, Kanjurmarg, Bhandup and Mulund. The estimated population of the three wards is 1,500,000. For administrative purposes the whole target area has been divided into 18 zones, each of which has one paramedical worker in charge, who carries out a full range of control activities, including surveys, casedetection, follow-up and health education, he also assists the medical officer during weekly visits to each zone. A field supervisor is responsible for the performance of 4 to 5 paramedical workers, and he in turn is supervised by the Project Officer, who is also 


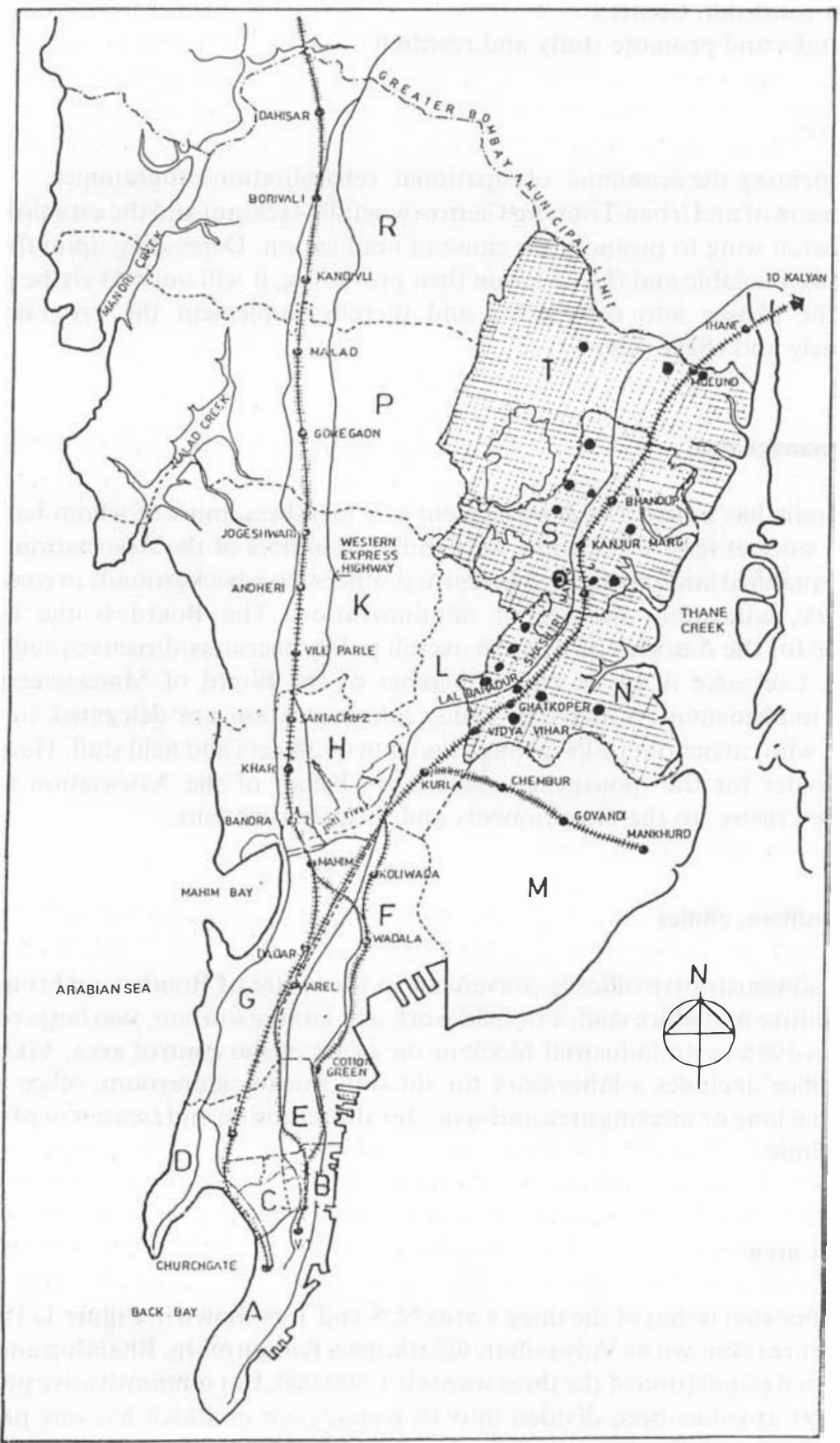

Figure 1. Map of Greater Bombay; total population 8 million. The letters $A-H, K-N, P, S$ and T ref er to 'wards' of Greater Bombay, of which N, S and T (shaded ara) are the control areas for ALERT-India. The area of the 'New Bombay Townships', in which programmes will be set up by ALERT-India in 1990, are to the right of Thane Creek, i.e. inland, towards the East. 
responsible for the planning and execution of the control programme as a whole. The medical officers are ultimately accountable for the proper implementation of all technical and professional aspects of the programme and are directly responsible for the diagnosis and treatment of all patients. Every 3 months there is a general meeting of the entire staff, including health educators and the social worker to discuss problems and to review progress. Once yearly a general self-evaluation is carried out by field workers and officers, using a questionnaire, and the outcome discussed at a meeting, chaired by the Chief Executive.

\section{Staffing}

This includes: 1, the Chief Executive (with qualification in social welfare administration); 2, two full-time medical officers (one of them functioning as the Project Officer); 3, four field supervisors (trained paramedical workers); 4, twenty paramedical workers, all of whom have had inservice training with ALERT-India and in Government recognized training centres; 5, one smear technician; 6, one physiotherapist; and 7, one social worker (female; with a degree in social work), one driver and one typist. One paramedical worker is responsible on average, for about 50,000 people, with four field supervisors for 20 paramedical workers. Fifteen out of the 20 paramedical workers are already trained as health educators and the rest will complete their training in health education in 1991 .

\section{Control policy and field activities}

These follow essentially conventional lines, as laid down (and used widely in India) by the National Leprosy Control (now Eradication) Programme in 1954. ${ }^{1}$ This is based to a large extent on the principle of 'survey education and treatment'. Surveys have been carried out in this project in: 1 , the general population; 2 , contacts of known cases and 3 , schools. In addition, a considerable number of cases are referred from private practitioners and others are apparently entirely self-reporting. Through the 9 years of operation, the approximate percentages of cases found in the above categories are: $1,37 \% ; 2,16 \%$ and 3 , $12 \%$. From the 18 zones referred to above in the three wards of this project, one is still to be surveyed, but in the others surveys have been completed on a door-to-door basis, identifying slum colonies, one room tenements and lower middle-class housing societies in each zone of the project area. These teams examine $80 \%$ of the population in every cluster. Anyone familiar with conditions in the slums of Bombay will readily agree that this is neither complete nor satisfactory as a basis for 'survey' and it is likely that the teams fail to contact some members of the community, including those who leave the house early to go to work, even if visits are repeated. It has also to be appreciated (see Discussion) that the population is to some extent 'shifting' due to employment opportunities in the City or in villages which defy monitoring. All survey activity has been accompanied, from the early years of the work of ALERT-India, by intensive health education, using verbal communication, leaflets and pictures of early leprosy, and the attempts which have been made to assess its value will be discussed below. 


\section{Treatment}

Nineteen clinics are scattered throughout the project area and they are held weekly, each patient receiving medication for 4 weeks at a time, on the occasion of attendance for supervised drugs. The regimens followed are those advised by the World Health Organization (WHO) in $1982^{2}$ (not those of the National Leprosy Eradication Programme) and the criteria for the grouping of patients for pauci or multibacillary regimens are also those of $\mathrm{WHO}$, with the following modifications: 1, All patients with less than 4 lesions are treated as pauci-bacillary; 2, all patients with 10 or more lesions are treated as multi-bacillary, regardless of bacteriological findings (i.e. even if negative); 3 , all cases with between 4 and 9 lesions, and less than 3 nerves involved, are treated as paucibacillary; and 4, all cases with more than 4 lesions and more than 3 nerves involved are treated as multibacillary. Pure neuritic cases with only 1 or 2 nerves involved are treated as paucibacillary and those with multiple nerves involved as multibacillary, but only after thorough examination and assessment by a medical officer. The periods of treatment are also essentially those advised by WHO, with the following modifications:

1 All paucibacillary cases are allowed a maximum of 9 months to complete the course of 6 supervised doses.

2 If a medical officer confirms that there is clinical activity on completion of the 6 months course, treatment may be continued for a further 6 months.

3 Triple drug therapy for multibacillary cases should be completed within 36 months, or continued until smears are negative and or clinical inactivity, whichever is the longer.

4 In certain cases, however, at the discretion of the medical officer, treatment for multibacillary cases has been stopped after 40 supervised doses, regardless of bacteriological positivity.

It is important to note that multiple drug therapy is given only to patients who are able to give an address or contact point; who understand what is needed by way of monthly attendances and daily, unsupervised treatment; and who agree to keep in touch with the programme for the necessary period of time. Unless these criteria are met ALERT-India, in common with other agencies doing leprosy work in Bombay, has not used multiple drug therapy. These patients are either given a supply of dapsone $100 \mathrm{mg}$ to take daily, with a prescription or a letter introducing them to the health services in another part of India, if they intend to leave Bombay. This policy, developed because of the danger of issuing expensive and potentially toxic drugs to patients who might never appear again, is judged now to be increasingly unacceptable, and alternative strategies to ensure that all patients presenting with active leprosy, especially if multibacillary, receive multiple drug therapy, are under discussion (see Research).

\section{Drug supplies and distribution}

Dapsone, clofazimine and rifampicin are supplied loose in stock bottles or plastic containers and made up into 1-month supplies (in the case of dapsone and clofazimine) for dispensing to patients. Blister packs, already widely used in some other parts of India, have not been used in this project, nor to our knowledge, in other parts of Bombay. Their 
use in the future, especially if advantages in compliance are demonstrated by trials, has not however, been ruled out. Based on personal interviews with patients, pill counts, occasional checks of the urine for dapsone and assessment of the clinical and bacteriological results, our impression is that compliance to prescribed medication is satisfactory.

\section{Planning, monitoring and evaluation}

From the earliest stages of work, attention has constantly been given to the yearly development of a 'plan of work', identifying priority areas for attention, writing specific objectives and drawing up a monthly timetable of work for all members of the team. Monthly progress and work reports have been in use throughout, including specific suggestions for the improvement of work performance. Quarterly reviews and reports are made by the Project Officer, including an analysis of achievements (or failures) in priority areas. Half yearly and yearly evaluations are made by the Chief Executive, including an analysis of the overall achievements of the Association, based on the set objectives. Of particular importance are the operational assessments which have been carried out every 3 years by an external team (usually 3 or 4 experts in the field of leprosy control), to assess the quality of work, achievements and overall plan of action, whilst at the same time making proposals for changes, corrections and improvements for the future.

\section{Referral of reactions, complications, cases requiring hospitalization}

It is of interest that the need to refer patients for any of these reasons has been remarkably low. It has in fact been necessary to refer patients for severe reactions or other serious complications on less than 100 occasions, during the 9 years of the programme. We have been fortunate to have excellent contact with the staff and facilities of the Vimala Dermatological Centre, to whose physicians we are extremely grateful. Patients stay in hospital for a minimum of time needed and then return to our care. The entire element of 'removal' to an isolated leprosarium has thus been avoided by an almost totally outpatient approach and this may have contributed to the high level of interest and cooperation by patients and the community.

\section{Laboratory services for slit-skin smears}

Facilities for taking smears are available in all 19 clinics of the project area. Sites are selected either by a medical officer or by the next most highly experienced paramedical worker available. Smears are taken and fixed by a laboratory technician or a paramedical worker trained in this procedure. Until the end of 1985, patients with less than 4 lesions were not routinely smeared, unless requested for some special reason. The present policy is that all cases are smeared prior to starting treatment, the only exception being children with a single lesion on the face. Appropriate instructions have been issued to Medical Officers concerning the possibility that multibacillary patients, who are partially (and perhaps inadequately) treated, or relapsing, may present with less than 4 lesions. Once 
fixed, labelled and dated, smears are sent to the 'Project Office' in Vikhroli, where one laboratory has been maintained through the years for the staining, examination and reporting of all smears, in accordance with advice given in a recent publication on the subject, ${ }^{3}$ to the effect that selection and taking may be peripheral, but the staining and interpretation should be centralized and constantly under supervision. The bacteriological index (BI) only is recorded, not the morphological index (MI) or any other index. One technician has been trained at the Schieffelin Leprosy Research and Training Centre in Vellore, South India. It has been possible only during the last 2 years to organize reliability or comparability checks with other centres in India, but medical officers check approximately $5 \%$ of smears on a random basis. Particularly in view of the recent recommendations by $\mathrm{WHO}^{4}$ that the finding of a positive $\mathrm{BI}$ at any site means that the patient should receive the multibacillary regimen ( 3 drugs for a minimum of 2 years), all slides with a BI of 1 will be double checked by a medical officer from now on.

\section{Records, registers and reports}

In recent years, following recommendations made by independent consultants, the number of registers and reports has been considerably reduced, but it is still necessary to supply them for three different agencies: 1, ALERT-India itself; 2, the Government of Maharashtra; and 3, the International Federation of Anti-Leprosy Associations (ILEP) in London. (The OMSLEP recording system has not been used.) The forms in use for ALERT-India for clinical details, smear reports, survey findings, contact examinations, etc., are entirely conventional and relatively easy to complete, but the monthly progress report for the Government is a lengthy and somewhat complicated document of 24 pages, which is time consuming for the health staff concerned, but nevertheless obligatory for administrative purposes. The ILEP Questionnaire or Form BG called for over 150 separate items of information, and although these are for the most part readily available from other sources and the form is required only once a year, it is clear that health staff are generally being asked to allocate an unreasonable amount of working time to the completion of these and other forms. Our belief is that the most important items which require recording are: 1 , the total number of patients registered; 2 , the number on multiple drug therapy; 3 , the number who have satisfactorily completed it and been released from treatment; and 4 , the proportion of new and currently registered cases with significant disability.

\section{Healthy contact survey examination}

As far as possible all contacts of index cases are examined once yearly, except contacts of multibacillary cases, who are examined every 6 months. The total number of contacts examined between 1981 and the end of 1989 was 48,060 from which 1189 cases $(2 \cdot 4 \%)$ have been diagnosed as having leprosy and treated.

\section{School surveys}

To date 249,122 school children have been examined, all between the ages of 5 and 15 
Table 1. ALERT-India 1981-89: population covered, new cases detected and prevalance rate per thousand

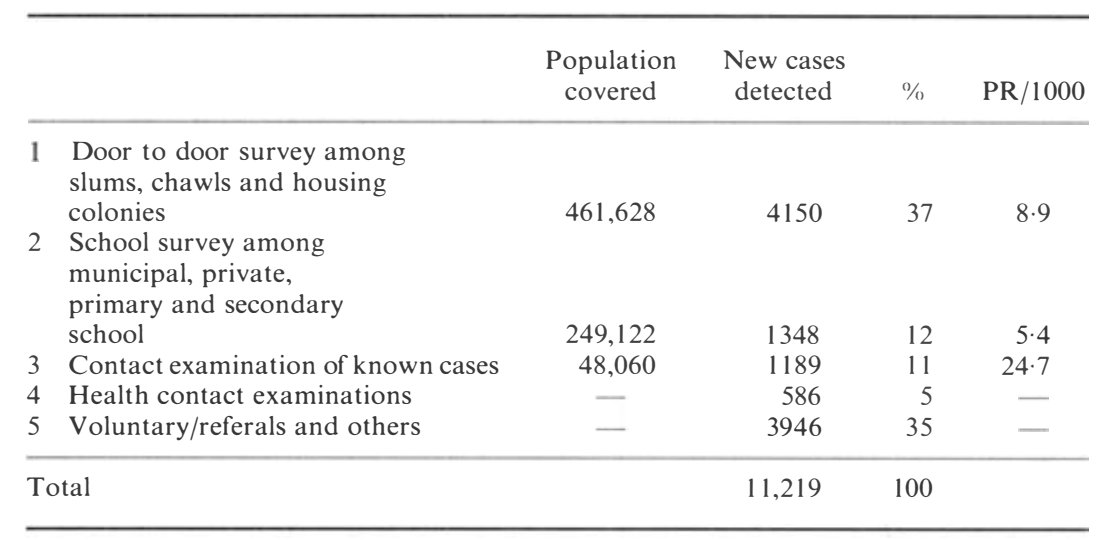

years. The case detection rates per thousand in recent years have been as follows: 1, $1984-4 \cdot 16 ; 2,1985-4 \cdot 66 ; 3,1986-9 \cdot 79 ; 4,1987-6 \cdot 4 ; 5,1988-4 \cdot 2 ;$ and $6,1989-5 \cdot 7$. The overall prevalence of new cases among school children was 5.4 per 1000 .

\section{Rehabilitation}

This term appears in the title of ALERT and in the 'Plan of Action' of 1978, but in the sense of mental and physical rehabilitation of disabled patients to enable them to find gainful occupation, it has not been possible to develop this activity with much effect. Although this has been largely due to lack of trained staff, premises and equipment, it became clear after only a few years of experiences that it is extremely difficult, probably unrealistic, to rehabilitate patients in a community where there is already unemployment amongst healthy people, or to train them for useful work in remote villages, if they intend to return home. In the more general sense, we continue to teach disability prevention and self-care by patients, but incline increasingly to the view that the treatment of seriously disabled patients and their rehabilitation should be undertaken by agencies which have the staff, expertise and premises, and who are prepared to integrate leprosy patients with those disabled from other causes.

\section{Public reactions to house-to-house and other forms of survey}

We had anticipated opposition and refusal to allow health staff to enter houses and examine occupants, but this occurred on only a very small number of occasions. A second visit, once confidence has been established, usually meets with complete success. We attribute such good relations to: 1, the careful orientation of staff before they embark on this kind of work, to ensure that they proceed diplomatically and with respect for the privacy and convenience of others; and 2, the fact that the slum populations of Bombay are now more than used to visitors, students and health or social workers of various kinds; 
Table 2. ALERT-India 1981-89: yearly case detection, child and disability rates, smear positive cases

\begin{tabular}{|c|c|c|c|c|c|c|c|c|c|c|c|}
\hline & & 1981 & 1982 & 1983 & 1984 & 1985 & 1986 & 1987 & 1988 & 1989 & Total \\
\hline 1 & $\begin{array}{l}\text { Total cases detected in each year (Annual) } \\
\text { (new \& old cases) }\end{array}$ & 847 & 1416 & 1615 & 1019 & 1921 & 2038 & 1018 & 1094 & 1088 & 12,056 \\
\hline 2 & New cases among the above & 847 & 1313 & 1517 & 964 & 1875 & 1831 & 896 & 988 & 988 & 11,219 \\
\hline 3 & Percentage of new cases & 100 & 92 & 94 & $94 \cdot 6$ & $97 \cdot 6$ & $89 \cdot 8$ & 88 & $90 \cdot 3$ & $90 \cdot 8$ & 93 \\
\hline 4 & Child cases among the new cases & 213 & 402 & 627 & 266 & 349 & 586 & 285 & 440 & 326 & 3494 \\
\hline 5 & $\begin{array}{l}\text { Percentage of child cases } \\
\text { (new cases) }\end{array}$ & 25 & $30 \cdot 6$ & $41 \cdot 3$ & $27 \cdot 5$ & $18 \cdot 6$ & 32 & $31 \cdot 8$ & $44 \cdot 5$ & 33 & 31 \\
\hline 6 & $\begin{array}{l}\text { Det ormed (Grade } 2 \& 3 \text { ) } \\
\text { cases among new cases }\end{array}$ & 45 & 47 & 76 & 42 & 76 & 85 & 35 & 40 & 47 & 493 \\
\hline 7 & $\begin{array}{l}\text { Percentage of deformed cases } \\
\text { (new cases) }\end{array}$ & $5 \cdot 3$ & $3 \cdot 5$ & 5 & $4 \cdot 3$ & 4 & $4 \cdot 6$ & $3 \cdot 9$ & 4 & $4 \cdot 7$ & $4 \cdot 4$ \\
\hline 8 & Smear positive cases among new cases & 28 & 76 & 97 & 54 & 132 & 165 & 94 & 78 & 74 & 798 \\
\hline 9 & $\begin{array}{l}\text { Percentage of smear positive cases } \\
\text { (new cases) }\end{array}$ & $3 \cdot 3$ & $5 \cdot 7$ & $6 \cdot 3$ & $5 \cdot 6$ & 7 & 9 & 10 & $7 \cdot 8$ & $7 \cdot 4$ & 7 \\
\hline
\end{tabular}

Table 3. ALERT-India 1981-89: total of registered cases, chemotherapy, cases released from treatment or lost to control

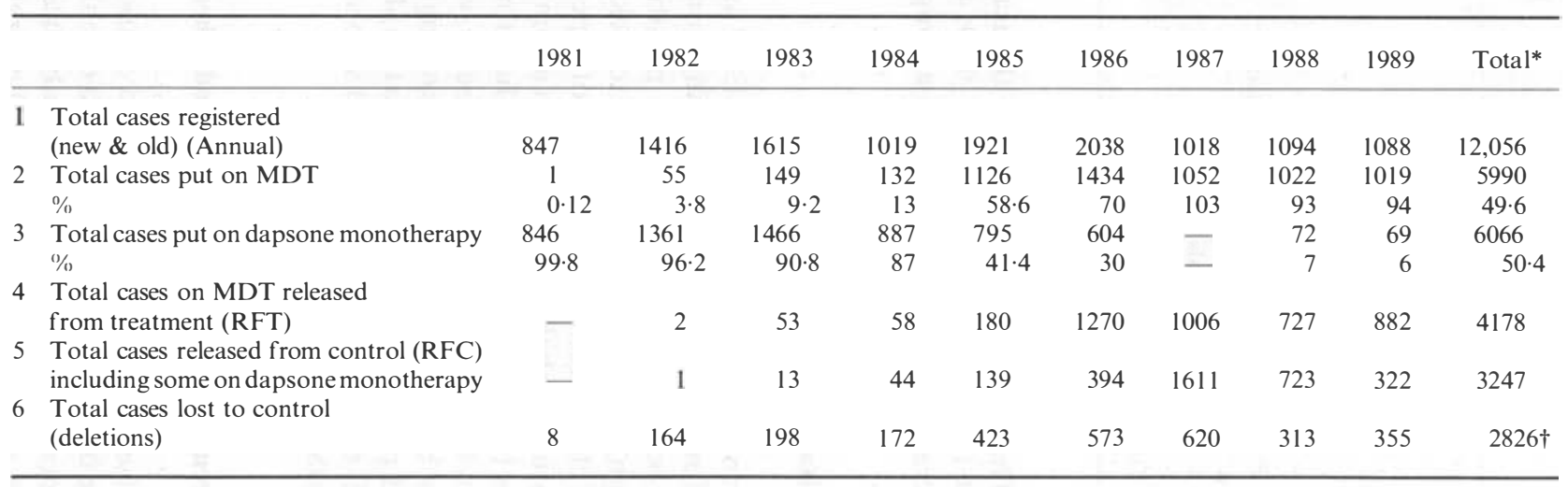

* The figures in this column have to be interpreted in the light of the fact that $15 \%$ of all cases are still on MDT or monotherapy at the time of writing this report.

$\dagger$ Anecdotally, information from social workers in ALERT-India and other agencies working in leprosy control in Bombay, indicates that many of these patients have transferred to other parts of the City and re-registered for treatment. 
once assured that the enquiry has nothing to do with legal matters, they are in general highly cooperative. Female staff work in pairs and appear to be able to carry out their duties with complete safety.

\section{The personal health record of staff in ALERT-India}

In the 9 years of operation in the slum areas described, often under conditions of great heat and without facilities for washing, etc, it is notable that we have had a low incidence of viral or other illnesses in doctors or paramedical workers. This is despite frequent contact with people suffering from measles, typhoid, dysentery, hepatitis, influenza, respiratory infections of various kinds, including active tuberculosis. During the 9 year period only one case of leprosy (pauci bacillary) has been diagnosed in an employee. Parttime or voluntary workers have included male and female students in their teens, none of whom has contracted a significant illness to our knowledge.

\section{Research}

ALERT-India has always been open to liaison with medical schools, universities and scientists, but with priority for operational and 'field-based' research on urban leprosy control and the extraordinary sociological conditions which prevail in the slum conditions of the project area. Pressure of work and lack of time have to a considerable extent precluded adequate attention to such research but we have had many visitors from different parts of the world and in 1987-88 data was collected by Dr Atul Vadher (Department of Experimental Psychology, Oxford University) which will contribute to a thesis on social and psychological aspects of leprosy in relation to compliance to prescribed medication. ${ }^{5}$ More recently, Dr Nigel Crook (Department of Economic and Political Studies, School of Oriental and African Studies, The University of London) has completed a final assessment of a study of the 'educational campaign method' which started in Maharashtra Nagar in early 1986, which is due for publication in the near future. ${ }^{6}$ Another study of sociological and population data in the New Townships of Vashi and Turbhe, with a preliminary estimate of the number of leprosy cases in those areas, has been submitted for publication. ${ }^{7}$

At least two other subjects calling for operational research remain and they are both of potentially great importance to the immediate plan of action. The first concerns the disconcertingly large number of patients who present, or are discovered to have leprosy in ALERT-India, but who are unable to give an undertaking that they will be in the area long enough to take a course of multiple drug therapy. Some of these are transient or visiting; others intend to return to their villages in the near future; others are unable to give an address or point of contact for supervision and follow-up, or are judged for a variety of reasons to be unlikely to pursue daily self-medication and monthly attendances for a reasonable period of time. To deny these patients any form of treatment or to give them dapsone monotherapy is an unacceptable policy which is now under intensive review in this organization. There are, however, good reasons for concluding that this problem (which occurs in slum programmes in several other parts of India) cannot be solved without consultation between ALERT-India, all other agencies working in leprosy 
control in Bombay, the Ministry of Health of Maharashtra and probably also the national Leprosy Eradication Programme of India. Meanwhile, we have outlined a pilot research programme to: 1 , identify the patients concerned in greater detail; 2 , define the sociological and other reasons which impede safe implementation of multiple drug therapy; and 3, propose solutions.

The second subject concerns the remarkably large number of private practitioners in the $\mathrm{N}, \mathrm{S}$ and $\mathrm{T}$ wards of this project and the likelihood that many more will settle in the New Townships in the coming years. The potential of private practitioners in Bombay in cae-detection and referral for treatment has already been shown to be considerable and it is now our intention to compile a comprehensive list of all practitioners in the area and to invite their cooperation, whilst at the same time carefully respecting their right to receive and treat patients as they see fit, and any element of professional confidence which may be involved. This enquiry will include information on the controversial question: 'Does the acceptance and treatment of leprosy patients in private practice enhance, or damage, the reputation of the doctor and the numbers of patients who come for consultation?'

\section{Discussion and future plans}

The registration of over 12,056 cases in a period of 9 years, followed by the release from control of over 7425, after completion of satisfactory courses of treatment, would appear to be a significant contribution towards the control of leprosy in the urban slums of this project. The disease has obviously been arrested in a large number of individuals; nerve damage has been prevented; relapse rates are low and there is at least a possibility that we have reduced the pool of infectious/contagious cases. There remain, however, a number of disconcerting aspects to this work, including the fact that we continue to register about 1000 new cases each year, but have little knowledge of their source of infection, whether within the project area or from some other part of Bombay (or India). We are also uncertain about the cost-effectiveness of our approach to case-detection and treatment. Survey can be laborious, time-consuming and expensive and it is notorious for the 'discovery' of cases who are unlikely to accept the diagnosis of leprosy and attend well for treatment. Broadly based educational campaigns, using all kinds of media, have been found by Ganapati ${ }^{8}$ and others to have advantages over routine survey and it is to be hoped that the study already referred to in Maharashtra Nagar will contribute further information in this area.

Under Treatment it has already been pointed out that a considerable number of patients with active leprosy do not, for a variety of reasons, receive multiple drug therapy and this is a matter of considerable concern which points to the need for some kind of central or coordinating body amongst the agencies working in leprosy control in Bombay. It should not be impossible to analyse and overcome the operational and other obstacles which give rise to this situation, whilst at the same time reviewing working methods, report forms, records and other matters of mutual interest to the 10 agencies concerned.

As already indicated, ALERT-India is now entering a new phase of work in the Townships of New Bombay and this may point to the urgency of making sure that baseline data are properly assembled and that data from the main project areas is analysed to greater advantage. We aim to educate the public and prevent disability through early case detection and chemotherapy. To do this effectively, we have to 
constantly keep in mind the need to study not only the disease and the drugs available for treatment, but also the complex and challenging pattern of society in the slums where we work.

\title{
Acknowledgments
}

We are grateful to Dr Claire Vellut, Ms Simone Liegeois, Dr M S Nilakanta Rao, Dr D Lobo and Mr M S Mehendale for permission to use information recorded by them in their Second and Third Operational Assessments of ALERT-India, Bombay, 1987 and 1990.

\section{Ref erences}

1 National Leprosy Eradication Programme. Leprosy Division, Directorate General of Health Services, Nirman Bhavan, New Delhi, India; National Leprosy Eradication Programme in India, 1987. Guidelines for Multidrug Treatment in Endemic Districts.

2 WHO Study Group. Chemotherapy of leprosy for control programmes. Technical Report Series No. 675. WHO: Geneva, 1982.

${ }^{3}$ Georgiev GD, McDougall AC. A re-appraisal of clinical and bacteriological criteria in the implementation of multiple drug therapy for leprosy control programmes and proposals for their better use. Special article. Lepr Rev, 1990; 61: 64-72.

4 WHO Expert Committee on Leprosy. Sixth Report. Technical Report Series No. 768. WHO: Geneva, 1988.

5 Vadher A. Patient treatment compliance in leprosy: a social psychological perspective. Thesis for degree of Doctor of Philosophy, Department of Experimental Psychology, University of Oxford. In preparation, 1991.

${ }^{6}$ Crook N, Ramasubban R, Samy AA, Singh B. An educational approach to leprosy control; an evaluation of knowledge, attitudes and practice in two poor localities in Bombay, India, 1991. 1991; Submitted for publication.

7 Samy AA, Mancheril J, Ammu L. Leprosy in the Vashi and Turbhe townships of New Bombay: a preliminary report based on house-to-house and school surveys. Submitted for publication.

${ }^{8}$ Ganapati R, Revankar CR, Bandkar KR, Dongre VV. Leprosy detection through non-survey techniques. Int J Lepr, 1984; 56: 622-5.

\section{ALERT-India 1981-89: Une expérience de 9 ans du contrôle de la lèpre dans les taudis de Bombay}

\author{
AA Samy, J Mancheril, K P Manek et A C McDougall
}

Résumé Bombay a une population d'environ 8 millions d'habitants dont la moitié vit dans des taudis. En 1981, ALERT-India commença son premier projet de contrôle de la lèpre dans les quartiers $\mathrm{N}, \mathrm{S}$ et $\mathrm{T}$ de la municipalité du grand Bombay d'une surface de $122 \mathrm{~km}$ carré dans les faubourgs nord-est de Vidhyavihar, Ghatkopar, Vikhroli, Kanjurmarg, Bhandup et Mulund dont la population totale s'élève à 1.100 .000 habitants d'après le recensement effectué en 1981. Au cours des neuf années d'activités, plus de 12.000 patients ont été enregistrés et soignés dont 7425 chez qui le traitement a été arrêté ayant terminé avec succes un traitement complet de chimiothérapie. Toutefois, plus de 1000 cas sont encore identifiés chaque année par des enquêtes à domicile ou dans les écoles ou par notification volontaire et comprennent un grand nombre d'enfants. La création, le développement, le personnel, les méthodes de travail, l'administration et la méthode d'enregistrement utilisée par ALERT-India sont décrits en détail. L'accent est mis sur les résultats obtenus uniquement en consultations hospitalières externes avec l'aide des paramédicaux qui ont tous reçu une formation spécifique en cours d'emploi dans des centres de formation reconnus par le gouvernement. Le rapport inclut une brève description de l'essor des activités de l'organisation dans les banlieues de New Bombay où les enquêtes préliminaires effectuées en 1988 confirmaient l'existence de lépreux et la nécessité de dispensaires. Les questions abordées sont les suivantes: 1, l'emploi plus judicieux des données statistiques recueillies par ALERT-India au cours des 9 dernières années soulignant leur importance sur l'évaluation de l'impact du programme de contrôle et sur l'évolution des politiques futures; 2 , la nécessité de comparer en détail le programme actuel d'enquêtes au système de campagnes éducatives afin de proınouvoir le dépistage des cas précoces et les notifications 
volontaires; 3, la création d'un organisme central de coordination pour le contrôle de la lèpre à Bombay permettant l'échange d'information, la coordination des efforts et la formulation de plans d'action futurs en association avec le Programme National d'Eradication de la Lèpre; 4, la création d'un centre de ressources en matière d'éducation sanitaire avec la Municipalité de Bombay.

\title{
ALERT-India 1981-89: Nueve años de experiencia en el control de la lepra en los barrios pobres de Bombay
}

\author{
A A Sämy, J Mancheril, K P Manek y A C McDougall
}

Resumen Bombay tiene una población de alrededor de 8 millones de personas, de las cuales la mitad vive en barrios probres. En 1981, ALERT-India inició su proyecto de control de la lepra en los distritos N, S y T de la Corporación Municipal de Gran Bombay cubriendo un área de $122 \mathrm{~km}$ cuadrados en los suburbios del nor-este de Vidhyavihar, Ghatkopar, Vikhroli, Kanjurmarg, Bhandup y Mulund, con una población total de 1.100.000 de acuerdo con el censo de 1981. En los 9 años de operación, más de 12.000 pacientes han sido registrados y tratados y de éstos 7425 han sido liberados del tratamiento, habiendo completado en forma satisfactoria cursos de quimioterapia. Sin embargo, más de 1000 casos son todavía identificados cada año en las encuestas casa por casa o en las escuelas o por auto informe, incluyendo un porcentaje considerable de niños. Se describe en detalle el origen, el desarrollo, la estructura del personal, los procedimientos operacionales, la administración y el sistema de registro de ALERTA-India, con énfasis en lo que se ha logrado con facilidades para pacientes ambulatorios solamente, usando trabajadores paramédicos, todos los cuales han recibido entrenamiento, durante su funcionamiento, de centros de entrenamiento reconocidos por el Gobierno por sus tareas específicas. $\mathrm{El}$ informe incluye una descripción breve de una expansión del trabajo de la organización hacia los pueblos en Bombay Nueva, donde las encuestas preliminares en 1988 confirmaron la presencia de casos de leprosos y la necesidad de facilidades para su tratamiento. La discusión propone: 1, el mejor uso del gran volumen de información estadística que ha juntado ALERTA-India durante los 9 años pasados, con énfasis en su valor de evaluar el impacto del programa de control y de modificar la política futura; 2, la necesidad de examinar radicalmente la politica de encuesta presente, versus un 'enfoque de campaña educacional' con miras a aumentar la detección temprana de casos y el auto-informe; 3, el establecimiento de un cuerpo coordinador central para el control de la lepra en Bombay para intercambiar información, coordinar esfuerzos y formular un plan de acción futuro, este último en asociación con el Programa Nacional de Erradicación de la Lepra; y 4, el desarrollo de un centro d recursos para la educación en la salud en asociación con la Corporación Municipal de Bombay. 